\title{
Children's Daily Activities and National Context: Structural Opportunities or Cross-Cultural Factors?
}

\author{
Pablo Gracia ${ }^{+}$ \\ Trinity College Dublin \\ Joan Garcia-Román \\ Centre for Demographic Studies, UAB \\ Tomi Oinas \\ University of Jyväskylä \\ Timo Anttilla \\ University of Jyväskylä
}

\begin{abstract}
This study investigates how child and adolescent time use differs across Finland, Italy, Spain and the UK, four countries capturing clearly distinct policy and cultural regimes. Studying children's time use cross-nationally provides new understandings of the micro-macro drivers of children's daily activities with critical implications for their personal development, future lifestyles and identity formation. The study uses rich time-diary data from 2008-2015 for a pooled sample of children aged 10-17 from Finland, Italy, Spain and the United Kingdom $(\mathrm{N}=6,556)$, applying multiple linear regression models addressing (i) between-country and (ii) within-country variations. Findings are consistent with the Cross-Cultural Hypothesis by revealing that Finnish children spend the lowest time with parents and the highest time alone and with 'others', after accounting for multiple factors. In Italy and Spain, children's time with parents is the highest, and time alone and with others clearly lowest. The UK lies somewhere in between the Scandinavian and Mediterranean models. In 'familyoriented' Italy and Spain, children spend more time eating (i.e., having dinners), while in more 'individualistic' Finland and UK screen-based time is highest (i.e. mobile phone use). The Structural Opportunities Hypothesis receives little support. Parental education generally leads to more time in educational activities in all four countries, while maternal employment generally weakly predicts children's time use across activities and national contexts. Overall, the strong cross-national differences observed in child and adolescent time use do not seem driven by simple structural or socioeconomic opportunity contexts, but rather by cross-cultural differences in values around family relations and individuals' daily routines.
\end{abstract}

Keywords: Families and Children, Time Use, Cross-National Research, Structural Opportunities, Cross-Cultural Variations

Acknowledgements: A previous version of the paper was presented at European Population Conference (6-9 June, 2018). The authors want to thank participants for their excellent feedback on the paper.

+ Corresponding author: graciap@tcd.ie; Department of Sociology, School of Social Sciences and Philosophy, Trinity College Dublin, College Green 1; Dublin, Dublin 2, Ireland. 


\section{INTRODUCTION}

The study of child and adolescent time use is important for social scientists. How children and adolescents engage in daily activities directly affects their life-course development, personality traits and identity formation (Ben-Arieh \& Ofir, 2002; Hofferth \& Sandberg, 2001; Kuykendall et al., 2015; Larson \& Verma, 1999). Scholars have investigated the determinants of children's time use by looking at individual and household factors. Living in an intact family, in a home high socioeconomic resources, or having employed parents with friendly working hours has been found to be associated with children's time in developmental activities like family socializing, reading and academic-based activities (Gracia \& Garcia-Roman, 2018; Bianchi \& Robinson, 1997; Wight et al., 2009). While scholars have investigated children's time use from a micro-level approach, the macro-level perspective has been largely omitted from this literature. This study seeks to cover this important gap in the multi-disciplinary research on families and children.

We argue that structural or cultural factors at the macro level could influence children's time use. At the structural level, countries differ in family access to monetary and time resources (Cooke \& Baxter, 2010; Esping-Andersen, 2016; Sayer et al., 2004). These structural variations across countries might affect how children and young people take decisions and spend time in everyday life. For example, in countries with high levels of paternal and maternal labor force participation children could spend more time in activities away from parents, but this might be moderated by the existence of active family-friendly policies in the country. At the cultural level, social norms and cultural beliefs might influence children's daily activities (Craig \& Mullan, 2011; Esping-Andersen et al., 2013; Sayer \& Gornick, 2012). In countries with strong 'family-oriented' values, children might tend to engage in daily activities with family members (e.g., parent-child time, family meals), contrary to countries with more 'individualistic' beliefs, where children could orient more time to (un)structured activities away from parents (e.g., solitary time, time with friends). Our study helps to answer this important question by addressing cross-national variations in child time use. 
Our study focuses on four Western European countries capturing important variations in policy, work-family and cultural contexts: Italy, Finland, Spain and the UK. At the policy level, Finland shows strong 'universalistic' public policies that support dual-earner couples and high levels of work-life balance (Anttila et al. 2015). The UK has a 'liberal tradition', with limited state involvement in social redistribution across families, and work-family policies that prioritize maternal part-time employment (Lewis 2009). Italy and Spain represent cases with family-oriented regimes, having low levels of redistributive policies, and relatively low maternal employment rates for Western European standards (Esping-Andersen, 1999; Flaquer, 2000; Jurado Guerrero \& Naldini, 2018). At the cultural level, Finland shows a strong individualistic approach of promoting self-oriented values and children's autonomy outside the parental home, while in Italy and Spain the family plays a relatively central role in social relations, and the UK combines individualism with a private approach towards family life (e.g., Garcia-Roman et al., 2017; Inglehart et al., 2014; Kalmijn \& Saraceno, 2007). The comparison of these three regimes (e.g., Mediterranean, Scandinavian and Anglo-Saxon) allows us to ideally examine the micro-macro determinants of children's time use.

The study contributes to the scarce cross-national literature on child time use. To our knowledge, only two studies (Rees, 2017; Zuzanek, 2005) have examined child or adolescent time use cross-nationally. Zuzanek (2005) used time-diary surveys from 1980-2001 to investigate how individuals aged 15-19 engage in daily activities in ten high-income countries. Using pure descriptive averages, Zuzanek (2005) found that French adolescents are more likely to engage in non-screen leisure routines (i.e., family meals), as opposed to more "individualistic" countries like the UK, Canada or the US, where screen-based time was highest. Zuzanek (2005) used old time-diary data from a period prior to recent massive digital transformations, without controlling for demographic or socioeconomic factors in his analyses, and without addressing the relevant question of 'with who' children spend time (i.e., parents, alone, friends). Rees (2017) used data from the Children's Worlds Survey (2013-2015) on 16 countries with different income levels to investigate how children aged 12 
allocate time to some daily activities. Rees (2017) found that country wealth is negatively linked to children's (un)paid work and positively to structured leisure and electronic time. Yet, Rees' (2017) study comes from stylized time-use measures, which provide much poorer time-use estimates than harmonized surveys with time-diary data from a random day (Gershuny, 2000; Robinson \& Godbey, 1999). The limited evidence on children's time use from previous cross-national research clearly motivates our study on the micro-macro determinants of child time use.

We analyze four harmonized national time-diary surveys focusing on children and adolescents aged 10-17 from Finland, Italy, Spain and the United Kingdom. These age groups cover a much longer childhood span than most national surveys (i.e., Canada, US), which lack diary data on children under the age of 15 . Our statistical analyses provide rich cross-national evidence on children's multiple activities with implications for their personality traits and development, including concrete activities (i.e., educational time, screen-based time, active time) and shared time (i.e., with parents, with 'others', solitary time). By capturing multiple daily activities, we can ideally contribute to classical and contemporary social science debates on how individuals' lives (here children) differ across distinct macro-societal contexts. In so doing, our analyses provide new answers around the puzzle of whether cultural or structural factors in a given society influence the way children spend time in relevant activities for their personal development and identity formation.

\section{BACKGROUND}

\section{Children's Time Use: A Micro-Macro Approach}

Children's time use captures essential variations in their formation of attitudes, skills or personality traits. Two main levels of analysis can be addressed here. The first level deals with the type of activity. For example, children's time in educational activities — reading, studying, going to libraries - fosters their schooling performance, cognitive skills and cultural capital (De Graaf, De Graaf, \& Kraaykamp, 2000; Hofferth \& Sandberg, 2001), while socializing — social events, group activities— fosters their social capital (Coleman, 1990). Other activities might carry risks for child development. For example, 
while children's time allocated to screen-based activities (i.e., TV, mobile phones) is necessary and taken by granted in our digitalized world, excessive screen-based time can have negative health, cognitive, and socioemotional consequences (Booker et al., 2015: Wang, Bianchi \& Raley, 2005; O'Keeffe \& Clarke-Pearson, 2011). By studying children's daily activities, scholars can contextualize their potential personal development and identity formation.

The second key dimension of child time use is with who children spend time. Child time "with parents' establishes the base of their future cognitive and socio-emotional development (Cano et al., 2018; Gracia, 2015; Kail \& Mayer, 2016). Yet, time with 'others' in (un)structured activities fosters children's social and relational skills also, which are central for the individual formation of social capital during late childhood and adolescence (Coleman, 1990; Putnam, 2001). Children's 'solitary time' has also important consequences for children's personality traits. Time alone can strengthen children's and adolescents' autonomy for their own maturity and development, but this time can also lead to risks of depression, reduced well-being or low stimulation, especially when solitary time is not proactively chosen (Nguyen, Ryan \& Deci, 2018; Larson, 1990). In short, knowing how children spend time in specific activities, but also whether this time is with parents, others or alone, permits us to provide important evidence around children's present and future lives.

Our study adopts a micro-macro approach. Most studies on children's time use adopt a micro perspective. Apart from studying differences in children's individual attributes (i.e., age, gender), scholars have looked at family-level characteristics. Teenagers in single-parent families were found to spend less time on family socializing or having meals with parents, compared to those living in two-parent families (Wight et al., 2009). Parents' socioeconomic status has been found to be positively associated with children's and adolescents' time spent reading and studying, and negatively associated with time watching television (Belloni \& Carriero, 2008; Bianchi \& Robinson, 1997; Lareau, 2003; Schmidt \& Anderson, 2007; Wight et al., 2009). Maternal full-time employment can reduce children's time in educational activities, and especially among young children (Bianchi \& 
Robinson, 1997; Mullan, 2009; Wight et al., 2009). Also, maternal evening work has been found to lead children to increase time in unsupervised screen-based activities and to reduce time in educational and family activities, yet only among less-educated families (Gracia \& Garcia-Roman, 2018). That is, parental resources and time availability intersect in influencing children's time use.

Yet, the macro-level approach is largely omitted from the child time use literature. While there is ample cross-national research on adults' parenting, leisure or domestic work (Hook, 2006; Craig and Mullan, 2013; Gracia \& Ghysels, 2017; Sayer et al., 2004), cross-national evidence on how children or adolescents engage in specific daily activities, alone, with parents or others, remains surprisingly limited. Rees' (2017) and Zuzanek's (2005) studies, as mentioned in the introduction, offer some insights to answer these questions. Yet, as mentioned, these two studies either adopted a purely descriptive approach, without accounting for individual or household characteristics (Zuzanek, 2005), or were based on stylized time-use measures that lack the precision of time-diary data to study children's activities (Rees, 2017). Our study seeks to fill these important gaps in this literature.

\section{Four National Contexts of Children's Time Use}

The study focuses on four Western European countries that capture relevant differences in policy and cultural contexts. Table 1 summarizes such variations by addressing five key items: (1) welfare state solidarity; (2) maternal work typologies; (3) work-family balance support; (4) individualism versus familism; (5) socioeconomic inequalities.

[Table 1, around here]

Finland represents the Scandinavian model in our study, clustering with the Social Democratic regime (Esping-Andersen, 1999). The Finnish case presents very high rates of dual-earner couples with children, in which the mother typically works full time, having the highest average weekly working time among female employees across our four countries of study (35 hours) (Eurostat, 2017). Finland can be defined as a highly supportive work-family regime, where parents report high work-family balance levels in surveys, compared to Italy, Spain or the UK, with much lower levels 
of family-friendly work conditions (Anttila et al. 2015; Gracia et al., 2011; OECD, 2016; Tevenon, 2011). With high maternal employment rates, Finland has developed a generous child care provision system, which relates to the relatively low levels of maternal child care time in Finnish families with young children (Sayer \& Gornick, 2011). The latter might imply that parents in Finland give high levels of autonomy to children to develop independently outside the domestic sphere. In fact, the individualization literature (e.g., Triandis, 2018) and recent data from the World Values Survey (Ingleheart et al., 2014) suggests that, on average, citizens in Finland give high priority to autonomy and values of 'self-expression', compared to more family-based countries like Italy or Spain. Finland shows internationally low levels of structural inequalities. Despite growing social inequalities in the last decade, public institutions in Finland still provide generous public support to equalizing opportunities and resources across families with children (Nolan et al., 2014).

The UK represents the Anglo-Saxon model in our study. In the UK, a very high proportion of mothers are part-time workers. This fact, together with a cultural conception of child care as a private domain, is associated to the higher absolute levels of maternal child care time in the UK in relation to Scandinavian countries, like Denmark or Finland (Gracia \& Esping-Andersen, 2015; Sayer \& Gornick, 2011). Compared to Finland, work-family policies in the UK provide limited options for full-time workers to balance paid work and family life (Lewis, 2009). At the cultural level, liberal attitudes of individualism are consistently high in the UK, showing the highest levels of autonomy and self-expression values in recent World Values Surveys within our four countries of study (Inglehart et al., 2014). In terms of welfare state tradition, the UK is characterized by a marketoriented model of public policy, one in which institutions provide low levels of income redistribution, with generally limited public intervention (Gracia \& Ghysels, 2017; OECD, 2016)

The cases of Italy and Spain represent the Southern European regime. Spain, and especially Italy, show a higher proportion of families with a male breadwinner model, compared to the UK, and very especially to Finland. Low maternal employment rates partly explain the quite high levels of 
child care time among mothers in Southern Europe, compared to Scandinavian countries (Gracia \& Esping-Andersern, 2015). Both Italy and Spain provide limited support for working mothers and fathers to balance paid work with family life, which explains the high incidence of male-breadwinner couples and growing levels of part-time employment in both countries (Del Boca \& Wetzels, 2010; Esping-Andersen et al., 2013; Gracia \& Kalmijn, 2016). Culturally, both Spain and Italy display a widespread acceptance of strong family ties and high degrees of active family solidarity, compared to countries like Finland, in which individualistic norms are more integrated into family relations and social life (Garcia-Roman et al., 2017; Jurado Guerrero \& Naldini, 2018; Kalmijn \& Saraceno, 2007). While Italy shows higher levels of social spending than Spain, both Italy and Spain present elevated degrees of social inequality, as well as policies lacking active universal support to equalize opportunities across families and children (Gracia \& Ghysels, 2017).

\section{THEORETICAL FRAMEWORK}

In our theoretical framework, we propose two potential explanations of potential cross-national differences in children's time use: (1) the cross-cultural hypothesis and (2) the structural opportunities hypotheses.

\section{Cross-Cultural Hypothesis}

The Cross-Cultural Hypothesis assumes that culturally rooted differences in lifestyles, family relations and social norms are the main drivers of cross-country variations in children's time use. In countries where children's supervision is -to a high extent- assumed to occur outside the domestic sphere (e.g., Scandinavian countries), parents with young children are often less active in child care activities, compared to countries with a child care culture that prioritizes more the domestic sphere (Anglo-Saxon countries, Southern Europe) (Sayer \& Gornick, 2011). From this perspective, not only cross-country differences in parental care attitudes, but also differences in children's levels of autonomy and daily organization of time, would be motivated by different cultural values about the role of individuals and families in society. In a similar vein, higher levels of 'individualism' -the idea 
that individuals' lifestyles are moved by their own preferences and choices in organizing life outside "traditional" institutions (Triandis, 2018)- explains country differences in children's daily activities. Countries like the UK and Finland show high scores of individualization and self-expression values, while Italy and Spain have stronger family-oriented cultural values (Inglehart et al., 2014; Kalmijn \& Saraceno, 2007). This approach implies that in Finland, as a result of its high individualistic values and its strong culture promoting children's autonomy outside the domestic sphere, children's time use would disproportionately occur outside the parental orbit.

The Cross-Cultural Hypothesis states that Finnish children spend the highest amount of time in solitary activities and in activities without parents. By contrast, in Southern Europe -including Italy and Spain- children would share more time with parents, as opposed to time alone and with others, which captures less individualistic and more-family oriented cultural values. The UK, with high levels of individualism (Inglehart et al., 2014), but also with a strong ideology of promoting parental care in the private sphere (Sayer \& Gornick, 2011), might be in between these two poles, having a more even distribution of children's time alone, with parents and others. The cultural thesis also implies that Italian and Spanish children would disproportionately engage in "traditional" familyoriented leisure activities (e.g., family meals), while British and Finnish children would participate more in individualized activities associated with child autonomy (e.g., exercising, electronic activities). Crucially, the cross-cultural hypothesis states that socioeconomic and demographic factors play a minor role in explaining cross-country differences in children's time use.

H1a: Children in Finland spend less time with parents and more time alone and with others than children in Italy and Spain, while the UK lies in between the Mediterranean and Scandinavian poles, after controlling for multiple demographic and socioeconomic factors.

H1b: Italian and Spanish children are more active in traditional family-related activities (e.g., having meals), while Finnish and UK children rather engage in more individual-related activities (exercising, screen-based time), after controlling for multiple demographic and socioeconomic factors. 


\section{Structural Opportunities Hypothesis}

The Structural Opportunities Hypothesis argues that 'between-country' differences in child time use are not driven by cultural factors, but rather by micro and macro contexts of opportunity. This approach argues that the distribution of socioeconomic resources in society (Gracia \& Ghysels, 2017) and differences in parents' time availability related to work constraints (Presser, 1994) predict children's daily time use. Thus, country differences in children's time in solitary activities, activities with parents or activities with others might be cancelled out once cross-country variations in parents' observable characteristics are accounted for. For example, cross-country differences in child time use should disappear after accounting for country variations in maternal employment, which captures parental time availability to organize daily activities with children.

The Structural Opportunities Hypothesis also addresses 'within-country' differences in child time use. In Finland, where social inequalities are low (Nolan et al., 2014), resources might not explain much variation in the child daily activities. That is, potential gaps between low-educated and high-educated families in children's educational activities might be relatively modest in Finland, compared to Italy, Spain or the UK, where inequalities are higher and policies promoting equalization in parents' time and monetary resources are limited. Similarly, the effect of maternal employment on children's time use might be weaker in Finland, compared to Italy and Spain, as working parents in the former country have easier work-family balance conditions (Antilla et al., 2015). From this logic, differences in time use between children with employed and non-employed mothers might be modest in the UK, as many British working mothers are part-time workers with relatively high levels of time availability to supervise children's activities.

H2a: There are no significant cross-country differences in children's daily time use, once demographic and socioeconomic factors are considered.

H2b: Educational differences in child time use are lowest in Finland, while variations in child time use by maternal employment are higher in Italy and Spain than in Finland and the UK. 


\section{DATA AND METHODS}

\section{Data}

We use data from the most recent time use surveys from Finland (2009-10), Italy (2008-09), Spain (2009-10) and the United Kingdom (2014-15). The four surveys followed the basic guidelines of the Harmonized European Time Use Survey (HETUS), a comparable time-use survey across European countries. Time-diary surveys are regarded as the best statistical data to investigate how individuals spend time in specific daily activities (Bianchi et al., 2006). These surveys incorporate diaries of activities combined with individual and household questionnaire information. In the survey, respondents reported one or more diaries of activities along the 1,440 minutes (24 hours) of a random day of the year, including multiple activities, like reading, television, sleeping, socializing, using internet or doing exercise. Respondents fill the activity they are doing at different moments of the day (typically with 10-min time slots), indicating also whether they are together with one parent, with others or alone while engaging in the specific activity. The surveys provide individual and household level information that can be linked to the child diary.

Our sample includes individual diaries reported by children aged 10-17 who are students and live in either a single-mother or a two-parent household. Time-diary surveys frequently have low levels of response. Our surveys are not an exception in this regard; the general average response rate of our surveys is $60 \%$. To account for selection bias in non-response, weights are applied in order to provide robust nationally representative estimates for each country, correcting also for response day. We excluded cases with incomplete information in the mothers' work status or in other demographic variables ( $\mathrm{N}=8$ in Spain; $\mathrm{N}=97$ in Finland; $\mathrm{N}=173$ in Italy; $\mathrm{N}=241$ in UK). Households with working mothers and one-parent households were more likely to report missing information, with moderate associations that were generally constant across surveys. Weights at the country level to allow us to correct for response bias. The final number of diary observations in the study was 804 in Finland, 3063 in Italy, 1324 in Spain, and 1363 in the UK $(\mathrm{N}=6,556)$. 
In the surveys from Finland and UK most children filled two diaries (one on a weekday and another on a weekend), while the surveys from Italy and Spain contain only one diary per child (either on a weekday or weekend). Surveys from all countries contain household samples, which means there could be multiple children in some households of observation (i.e. siblings). Our empirical analyses fully account for the clustered nature of our samples at the household level, as well as for the possibility of having two diary days in the data from Finland and the UK. Weighted calculations are used to ensure that samples are representative, not only at the demographic level (by oversampling underrepresented groups) but with regards to the days of observation (by ensuring that every day of observation is represented equally across the week).

\section{Dependent Variables}

Our dependent variables include two levels of activities, referring to (1) 'with who' children spend time and (2) the 'specific activity' in which children engage. All dependent variables are measured as daily minutes on a random day within a random week of the year. For all the activities of study, we refer to the primary activity (excluding the secondary activity), as literature suggests that secondary activities (simultaneous to the main one) can differ across surveys and so including them can produce bias (Kitterod, 2001). We exclude from the analysis the following activities: sleeping, personal care, paid work, commuting, and "doing nothing." Additional analyses (not shown) reveal that UK children spend the highest time sleeping and in personal care. Yet, such differences are quite marginal, stable across the other three countries, and do not account for the statistical differences that we present in our analyses (results not shown).

As for with who the child spends time, we refer to daily minutes: (1) 'with parents' (with the mother or father at home, outside school time); (2) 'alone' (without presence of other individuals, outside school time); (3) 'with others' (any time without parents, but with other people, outside school time); (4) at 'school' (any time in activities within the school). Regarding specific activities, we code all activities in which the child is active in leisure, outside school (excluding sleeping, personal care, 
paid work, school time, commuting, and “doing nothing”): (1) 'screen-based time' (e.g., TV, videos, electronics, phones, video games); (2) 'educational time' (e.g., homework, reading, library time, cultural spectacles, doing arts, music); (3) 'socializing time' (e.g., social relations, playing, social games, volunteering); (4) ‘eating time' (e.g., meals, drinks); (5) 'active time' (e.g., exercising, active sports); (6) 'domestic work' (e.g., housework, child care). Details on the exact criteria and coding strategy can be found in Table A1.

\section{Independent Variables}

Regarding our independent variables, we use a dummy measure of 'country' within a cross-country pooled sample. Unfortunately, it is not plausible to run multi-level models with observations from only four countries (Bryan \& Jenkins, 2016), as variables at the macro-level (besides country) cannot be included in our statistical analyses. We define 'maternal employment', as a dummy measure that differentiates between $1=$ "mother works" and $0=$ "mother does not work". We further used four categories of maternal working time in some model specifications and robustness checks, based on the mothers" average weekly work hours $(0=$ "no work"; $1=$ "working from 1 to 30 hours"; $2=$ "working from 31 to 37 hours"; 3 = "working more than 37 hours"). We use a dummy variable of 'maternal education' that differentiates between children with a college-educated mother $(=1)$ and children with a mother not having a college degree $(=0)$.

\section{Control Variables}

We use several control variables. 'Family structure' differentiates between $0=$ "two-parent family" and $1=$ "single-mother family". 'Number of children' refers to the number of children aged 0-17 at home; 'number of adults' measures the number of adults at home aged 18 or older (ordinal variables). 'Gender' includes $0=$ "boy" and $1=$ "girl". 'Age' is used as a pure continuous variable in years. 'Day of the week' is a dummy variable that differentiates between $0=$ "weekday" (Monday-Friday) and 1 = "weekend" (Saturday-Sunday). 'Yearly Quarter' refers to the four annual seasons: $0=$ "1 1 st Yearly Quarter"; 1 = "2 $2^{\text {nd }}$ Yearly Quarter"; 2 = "3 $3^{\text {rd }}$ Yearly Quarter"; 3 = "4 $4^{\text {th }}$ Yearly Quarter". 


\section{Empirical Strategy}

Our analyses consist of Linear Prediction Models within a multivariate framework. We start by running Ordinary Least Squares' (OLS) regressions to measure children's time use. OLS models are considered to be robust techniques for observational time-diary data, considered to provide more robust estimates than Tobit models (Stewart, 2013). Accounting for all our control variables we, first, look at predicted differences in children's minutes allocated to each activity across all our four countries of study. Secondly, we estimate predicted values of children's time use with an interaction effect between maternal work and country, and subsequently interact parental education with country. Analysis look at (1) between-country and (2) within-country differences in children's time use. Empirical models are based on a pooled sample including all four countries of study. All analyses are stratified with demographic weights, including weights per day, week and season of year, using cluster robust standard errors accounting for within-household clustering of observations.

\section{RESULTS}

\section{Sample Distributions}

Table 2 presents the summary statistics of our variables of analysis. We observe that country differences by age (with a mean around 13 years old) and gender (around 50\%) are insignificant. The characteristics of families and mothers differ across countries. The number of children aged under 18 in the household is higher in Finland (2.12) and UK (2.14) than in Italy (1.77) and Spain (1.80), mirroring country variations in fertility rates. The proportion of single-mother families is highest in the UK (31\%), followed by Finland (21\%), Spain (16\%) and Italy (13\%). We also observe a much higher percentage of mothers who do not work in Italy and Spain, with -respectively- $43 \%$ and $38 \%$ of non-working mothers, a percentage that is lower in the UK (31\%), and much lower in Finland (18\%). We see that Finnish mothers disproportionately work full time, namely more than 37 hours per week $(56 \%)$. This proportion is low in the UK, where only $13 \%$ of mothers work more than 37 hours, being Italy (22\%) and Spain (33\%) in between the other countries. Finally, the proportion of 
mothers in the category of maternal college education also differs across countries, including $13 \%$ in Italy, 28\% in Spain, $43 \%$ in the UK, and 54\% in Finland.

\section{Multivariate Analyses: Cross-Country Variations}

Figure 1 shows the predicted linear models with cross-national differences in time spent by children in all our time-use activities, controlling for all the covariates included in the study. The results presented in this figure closely mirror the average time-use variables from Table 2 (see also Figure A1). This implies that adding demographic and socioeconomic variables does not have any relevant impact on cross-national differences in children's time use.

Figure 1 shows that time with parents is clearly at much lower level in Finland than in the other countries. Finnish children spent 131 minutes with their parents, 1 hour and 46 minutes less than in UK, and about 2 and a half hours less than children in Italy and Spain. By contrast, Finnish children spent the highest amount of time alone and with others. Finnish children spent about four hours alone, showing a much higher level than children from the other three countries, with close to 3 hours of time alone. Children from the UK also spent a significantly higher amount of time with others than children in our Mediterranean countries. Interestingly, in Italy and Spain children spent about 3 hours per day at school, while in the UK and Finland school time accounts for about 30 minutes less. Confidence intervals included in Figure 1 reveal that cross-country differences in 'with who’ time are, not only generally large, but statistically significant (CI: 95\% level).

Figure 1 also shows the predicted minutes on specific time-use activities, corresponding to the sum of non-school time with 'parents', 'others' and 'alone'. British and Finnish children's time use is more similar when we look at specific activities, even if their time with others and solitary time differs markedly. The largest cross-national differences are observed in screen time, education time and eating time. Predicted screen time is 3 hours and 18 minutes in the UK and 3 hours and 25 minutes Finland, which are between 30 to 60 minutes higher than in the two Mediterranean countries, with clearly significant differences. Children in Italy and Spain spend more time eating, but interestingly 
also in educational activities, adding more than 100 minutes in the both countries for each activity, with more than 30-minutes gaps with respect to children in the UK and Finland. These cross-national differences are generally significant at the $95 \%$ level (full details on CI are available upon request to the authors). For active and domestic work, the predicted minutes allocated by children are low, while cross-country differences are modest. Italian children spent only 33 minutes in domestic activities, 17 minutes less than children in the UK. Children from the UK spend only 35 minutes in active time, 15 minutes less than in Spain. Finally, the predicted minutes of social time among Spanish children is interestingly the lowest, being 15 minutes below Italy (105 minutes) and Finland (108), where children spend most time in socializing activities.

[Figure 1, about here]

\section{Multivariate Analyses: Within-Country Variations}

Figure 2 presents the interaction effects for maternal employment and country, using predicted values of child time use, controlling for all demographic and socioeconomic variables. Results clearly reveal marginal cross-national differences in the statistical effect of mother's employment on children's time use. For Finland, differences by maternal employment are low and insignificant, as with Italian and UK children. The only relevant difference with regards to maternal employment is found in Spain, only with respect to children's time with parents, with predicted values of 317 minutes for children with non-employed mothers and 264 daily minutes for children with employed mothers (95\% CI levels). For specific activities we generally observe marginal and insignificant differences in children's time use by maternal work status.

[Figure 2, about here]

Figure 3 presents the interaction effects for maternal education and country in predicting child time use. We can see relevant educational gradients in specific developmental activities, mirroring previous research (Bianchi \& Robinson, 1997; Gracia \& Garcia-Roman, 2018; Mullan, 2009; Wight et al., 2009). Yet the intensity of such educational gradient is not even across national contexts. In the 
UK, children with college-educated mothers spent 42 minutes less screen time, and 24 minutes more time in education activities, compared to children with less-educated mothers (95\% CI levels). Spain shows clear differences for screen-based activities (with 33-minutes gap) (95\% CI levels) and to a lesser extent in educational activities (14-minute gap). For Italy, the gradients by maternal education in educational activities were large and significant for educational time (33-minute gap), similar to Finland (30-minute gap) (95\% CI levels). Yet, interestingly, differences by maternal education in Italy and Finland are inexistent for screen-based activities, unlike in the UK and Spain. Regarding the other specific child activities, and the 'with-whom' set of activities, educational gaps are generally insignificant across the four national contexts of study.

[Figure 3, about here]

\section{Robustness Checks}

We conducted multiple robustness checks (all these additional results are available upon request to the authors). We first re-run all the analyses for a sample of children with employed mothers only to better address if the observed cross-national differences in children's time use are partly driven by selection into maternal employment. Results remained stable when looking only at families with

employed mothers. Similarly, within-country differences in child time use remained generally low when we used alternative categories of maternal employment in the interaction terms, including both categorical and continuous measures of mothers' weekly working hours. Indeed, with the exception of Spain regarding parent-child time, maternal employment is weakly associated with child time use across countries, irrespective of how we measure maternal employment.

We also conducted various robustness checks for parental education. Following the strategy of Guryan et al. (2008), we divided our sample into two groups, separating between the $50 \%$ most educated mothers and the other $50 \%$ least educated at the country level. Using these measures, educational difference in child time use remained stable. We further examined various specifications of education (with three/four levels), with results generally consistent with our main results. Not 
surprisingly, a dummy variable produces more robust results for certain subgroups, as some educational categories are underrepresented in some countries (e.g., mothers with basic education in Finland). When combining measures of maternal education with paternal education by using various empirical strategies, our findings supported the main results of the study. We can conclude that educational differences apply to screen-based (negative) and educational time (positive) in our large sample, while in Italy and Finland differences apply only to educational activities.

\section{CONCLUSION}

The present study is based on a comprehensive cross-national analysis of how child and adolescent time use differs between and within national contexts. While previous studies have analyzed country differences in adults' time and parent-child interactions (Craig \& Mullan, 2011; Gracia \& Ghysels, 2017; Kan et al., 2011; Sayer et al., 2004), the micro-macro determinants of children's daily activities have surprisingly received hardly any attention. How children engage in specific activities, and also whether they do it alone, with parents or others, provides key knowledge to better understand meaningful differences in children's lives, personal development or identity formation, which are all of them essential questions for family researchers. Previous cross-national studies are limited and rely on purely descriptive data (Zuzanek, 2005) or on statistical analyses using stylized measures of time use, which are subject to measurement error (Rees, 2017). Indeed, our time-diary study fills a relevant gap in the existing micro-macro literature on families and children.

We have proposed two alternative explanations of how children's time use differs across national contexts. The Cross-Cultural Hypothesis $(\mathrm{H}-1)$ argues that cross-country variations in norms and lifestyles are the main drivers of country differences in children's time use and, therefore, that country differences in child time use remain stable after accounting for multiple socioeconomic factors. By contrast, the Structural Opportunities Hypothesis (H-2) posits that children's time use is embedded into structural contexts of opportunities at the micro and macro level, which can explain significant variations in child time use, not only within, but also between countries. 
Our analyses are based on a cross-national investigation of four Western European national cases representing distinct policy and cultural regimes: Finland represents the Scandinavian context; Italy and Spain represent the Mediterranean model; UK represents the Anglo-Saxon regime. Our approach on these four national cases provides detailed estimates on the degree to which distinct micro-macro contexts lead to variations in children's time-use activities with various implications for their daily lives, personal development and future lifestyles. The analysis benefited from rich timediary data covering the period of 2008-2015, using a multidimensional measure of children's time use that provides very detailed estimates, not only on what children do, but also on with who children are (i.e., parents, alone, or others) across national contexts.

Findings reveal strong cross-country differences in children's time use allocation. After controlling for multiple factors, children in Finland spend 131 minutes with at least one parent on a random day, about half as much time as children in Italy (270 minutes) and Spain (280 minutes). The UK is in between the two but leaning to the Southern European case in parent-child time. By contrast, Finnish children disproportionately orient time to solitary activities (235 daily minutes), representing more than 1 hour per day, compared to Italy, Spain and the UK. Finland is also an outlier in activities with others, which include socializing, time with friends or extracurricular activities (circa 350 minutes). In more familial-based Italy and Spain we see radical differences in time with others, representing respectively close to 260 and 220 minutes in such time activities. In between these two extremes, we find the UK, with circa 300 minutes spent every day in activities without the presence of parents and with others. Interestingly, in family-oriented Spain and Italy, children equally spend the highest time eating (e.g., dinners at home), but also engaging in educational activities outside school, adding 30 minutes more than children in Finland and UK for exactly the same activities. By contrast, in more individualistic Finland and the UK, children disproportionately engage in screenbased activities, adding about 40-50 minutes more than children from Italy and Spain spend in the same screen-based activities (i.e., TV, mobile phone use, video games). 
Findings provide general support to the Cross-Cultural Hypothesis (H-1). Indeed, crossnational differences in children's time use remain salient after demographic and socioeconomic factors are considered. These results suggest that family-oriented values and forms of daily organization are strongly anchored in Southern Europe (Italy, Spain), with the highest time in parentchild activities. By contrast, in a country with stronger values of self-realization and weaker family ties (Finland), children's time use is more "solitary" based. Now, while Finland shows much higher levels of children's solo time than the other three countries, it is also an outlier in children's time with 'others', above the UK, and clearly above Italy and Spain. The latter, interestingly, breaks the stereotype that Scandinavians are per se less "social" than Southern Europeans. These results instead suggest that country differences in child daily "sociability" are not salient in the quantity of this time, but in its nature; that is, whether it is shared with parents or not.

Our results generally reject the Structural Opportunity Hypothesis (H-2). This implies that structural contexts of opportunities would not be central drivers of differences in children's daily activities across societies. Certainly, it is difficult to differentiate between "structural" and "cultural" factors with the available data (multi-level data for a large number of countries are currently limited). Yet, results suggest that cultural values -besides observable socioeconomic factors-are key. Only in Spain did maternal employment lead to less time with parents, not surprising considering the familyinflexible work constraints of Spanish mothers (Gracia \& Garcia-Roman, 2018; Gracia \& Kalmijn, 2016). Yet, for the other activities, child time use was unaffected by maternal work, and in all four countries. The finding was consistent when using various alternative measures as robustness checks. This implies that children's daily routines can be relatively unaffected by the mother's work status and working hours and that factors other than maternal constraints and its related time availability explain the significant country variations in children's time use.

While educational gaps in children's time use were more salient than gaps for maternal employment, these educational differences were not clearly consistent across national contexts. In 
line with previous studies, children with better educated mothers spent more time in educational activities, and generally less time in screen-based activities, compared to children with less-educated mothers (Bianchi \& Robinson, 1997; Gracia \& Garcia-Roman, 2018; Mullan, 2009; Wight et al., 2009). These findings were clearly pronounced in the UK and, to a lesser extent, in Spain. In both Italy and Finland children with high-educated mothers disproportionately engaged in educational activities, but educational differences in children's screen-based time did not apply in none of these two countries. At the household level, such results are partly consistent with the structural opportunities thesis, namely that material and cultural resources at home are associated with child developmental time use. Yet, differences across countries cannot be clearly interpreted along country variations in stratification patterns, as Finland and Italy -with different structural and policy contextsshow very similar patterns. More research in this direction will be certainly needed.

This study has implications for micro-macro debates on families and children. Our research suggests that observable socioeconomic factors (i.e., maternal work and parental educational), do not help us to understand most of the marked cross-national differences in children's time use. We claim that country differences in family routines and cultural traditions, historically shaped and contingent to endogenous complex socio-historical process, play a substantial role in explaining country differences in child time use. This approach implies that Finnish children do have a markedly different organization of their daily lives than British children, and especially compared to Italian and Spanish children, not because of their parents work status or resources, but rather because of cultural differences across these nations. While the cross-cultural explanation seems plausible, to further answer this question we will need studies with multi-level time-diary data containing information on children's attitudes and macro-level contexts, which are currently unavailable. Besides our detailed time-diary evidence on children's daily lives in cross-national perspective, we hope our study will be read in line of the theoretical questions raised regarding the role of structural factors, cultural attitudes or policy contexts in children's agency in their daily activities. 
Our study has some limitations. Currently, we lack multi-level time-diary data to address more specifically the micro-macro determinants of child time use. Indeed, we were not able to conduct a systematic multi-level study. Most surveys do not contain time-diary data from children under the age of 15/16. Even if our study, we argue, contributes significantly to ongoing theoretical and empirical considerations of the micro and macro determinants of children's daily activities, we have been unable to fully address the endogenous relationship between culture and structure, due to the current lack of suitable time-diary data for a larger $\mathrm{N}$ of countries.

Still, a lesson from our study is that differences in child/adolescent daily lives are enormous across industrialized countries with distinct policy and cultural regimes (e.g., Scandinavian, AngloSaxon, Southern European), visible in our results using high-quality time-diary data. Also, again, these differences do not seem to be explained by purely socioeconomic factors, like maternal employment or educational inequalities, but by other factors, arguably cultural values and attitudes. We argue that our results stress the role of culturally-driven distinct logics around families, individuals and children's lives, neglected in some previous academic debates. Future studies should gather specific data on social norms, policies and individual attitudes to re-test the micro-macro drivers of variations in children's daily activities with high-quality time-diary data.

To conclude, this study -despite it will need further replications and additional researchsuggests that, to understand children's daily lives and activities, scholars need to pay attention to the role of culturally driven forms of daily organization, besides socioeconomic factors. This task is arguably of central importance to understand cross-country differences in child time use. We hope our study will inspire new research, but also theoretical explanations benefiting from cumulative knowledge, that will address the critical question of how children's key daily routines and activities can be affected by both micro and macro level factors. 


\section{REFERENCES}

Anttila, T., Oinas, T., Tammelin, M., \& Nätti, J. (2015). Working-time regimes and work-life balance in Europe. European Sociological Review, 31(6), 713-724.

Belloni, M.C. \& Carriero, R. (2008). Childhood: A homogeneous generational group?, in Arnlaug Leira, Chiara Saraceno (ed.) Childhood: Changing Contexts (Comparative Social Research, Volume 25) Emerald Group Publishing Limited, pp.293-324.

Ben-Arieh, A., \& Ofir, A. (2002). Opinion, dialogue, review: Time for (more) time-use studies: Studying the daily activities of children. Childhood, 9(2), 225-248.

Bianchi, S. M., \& Robinson, J. (1997). What did you do today? Children's use of time, family composition, and the acquisition of social capital. Journal of Marriage and the Family, 332344.

Bianchi SM., Robinson JP \& Milkie MA (2006) Changing rhythms of American family life. New York: Russell Sage Foundation.

Booker, C.L., Skew, A.J., Kelly, Y.J. \& Sacker, A., (2015). Media use, sports participation, and wellbeing in adolescence: Cross-sectional findings from the UK Household Longitudinal Study. American journal of public health, 105(1), 173-17

Bryan, M.L. \& Jenkins, S.P. (2016) Multilevel Modelling of Country Effects: A Cautionary Tale. European Sociological Review, 32(1), 3-22.

Cano, T., Perales, F., \& Baxter, J. (2018). A Matter of Time: Father Involvement and Child Cognitive Outcomes. Journal of Marriage and Family. doi.org/10.1111/jomf.12532

Cooke, L. P., \& Baxter, J. (2010). "Families" in international context: comparing institutional effects across western societies. Journal of Marriage and Family, 72(3), 516-536.

Coleman, J. (1990). Foundations of Social Theory. Cambridge: Harvard University Press.

Craig, L. \& Mullan, K., 2012. Shared parent-child leisure time in four countries. Leisure Studies, 31(2), 211-229.

Craig, L., \& Mullan, K. (2011). How mothers and fathers share childcare: A cross-national time-use comparison. American Sociological Review, 76(6), 834-861.

De Graaf, N.D., De Graaf, P.M. and Kraaykamp, G., (2000). Parental cultural capital and educational attainment in the Netherlands: A refinement of the cultural capital perspective. Sociology of education 73(2): 92-111.

Del Boca, D. \& Wetzels, C.Ã., 2010. Social Policies, Labour Markets and Motherhood. Cambridge: Cambridge University press.

Esping-Andersen, G. (1999). Social foundations of postindustrial economies. Oxford: Oxford University Press.

Esping-Andersen, G. (2016). Families in the 21st Century. Stockholm: SNS förlag. 
Esping-Andersen G, Boertien D, Bonke J, \& Gracia P (2013). Couple specialization in multiple equilibria. European Sociological Review 29(6) 1280-1294.

Eurostat (2017). Employment statistics - European Commission, Brussels.

Flaquer, L .(2000). 'Is there a Southern European model of family policy?'. In A. Pfenning and T. 12 Bahle (eds.). Families and Family Policies in Europe. Franfurt a.m./New York: Peter Lang.

García-Román, J., Flood, S., \& Genadek, K. (2017) "Parents' time with a partner in cross-national context: A comparison of the US, Spain, and France". Demographic Research 36 (4): 111144.

Gershuny J (2000). Changing times: work and leisure in postindustrial society. Oxford: Oxford University Press.

Gracia, P. (2015). Parent-child leisure activities and cultural capital in the United Kingdom: The gendered effects of education and social class. Social Science Research 52(4): 290-302.

Gracia, P. \& Esping-Andersen G (2015). Fathers' child care time and mothers' paid work: A crossnational study of Denmark, Spain, and the United Kingdom. Family Science, 6(1): 270-281.

Gracia, P. \& García-Román, J. (2018) 'Child and Adolescent Developmental Activities and Time Use in Spain: The Gendered Role of Parents' Work Schedules and Education Levels'. European Sociological Review. 34(5), 518-538

Gracia P \& Ghysels J (2017). Educational inequalities in parental care time: Cross-national evidence from Belgium, Britain, Denmark, and Spain. Social Science Research 63(2): 166-180.

Gracia P, Ghysels J, \& Vercammen K (2011) Parental care time in four European countries: comparing types and contexts. Demosoc Working Papers, Pompeu Fabra Univ., num 41.

Gracia P \& Kalmijn M (2016) Parents' family time and work schedules: The split-shift schedule in Spain. Journal of Marriage and Family 78(2): 401-415.

Guryan, J., Hurst, E., \& Kearney, M. (2008). Parental education and parental time with children. Journal of Economic perspectives, 22(3), 23-46.

Hofferth, S. L., \& Sandberg, J. F. (2001). How American children spend their time. Journal of Marriage and Family, 63(2), 295-308.

Hofferth, S. L., \& Moon, U. J. (2012). Electronic play, study, communication, and adolescent achievement, 2003-2008. Journal of Research on Adolescence, 22(2), 215-224.

Hook, J.L., (2006). Care in context: Men's unpaid work in 20 countries, 1965-2003. American sociological review, 71(4), 639-660.

Inglehart, R., C. Haerpfer, A. Moreno, C. Welzel, K. Kizilova, J. Diez-Medrano, M. Lagos, P. Norris, E. Ponarin \& B. Puranen et al. (eds.). 2014. World Values Survey: Round Six - CountryPooled Datafile Version: http://www.worldvaluessurvey.org/WVSDocumentationWV6.jsp. Madrid: JD Systems Institute. 
Jurado Guerrero, T. \& Naldini, M. (2018). "Child and family policy in Southern Europe". In Guony Bjork Eydal [Ed] Handbook of Family Policy. Cheltenham: Edward Elgar Publishing.

Kalil, A., \& Mayer, S. E. (2016). Understanding the importance of parental time with children: Comment on Milkie, Nomaguchi, and Denny (2015). Journal of Marriage and Family, 78(1), 262-265.

Kalmijn, M., \& Saraceno, C. (2008). A comparative perspective on intergenerational support: Responsiveness to parental needs in individualistic and familialistic countries. European Societies, 10(3), 479-508.

Kan, M. Y., Sullivan, O., \& Gershuny, J. (2011). Gender convergence in domestic work: Discerning the effects of interactional and institutional barriers from large-scale data. Sociology, 45(2), 234-251.

Kitterød, R. H. (2001). Does the recording of parallel activities in time use diaries affect the way people report their main activities?. Social Indicators Research, 56(2), 145-178.

Kuykendall, L., Tay, L., \& Ng, V. (2015). Leisure engagement and subjective well-being: A metaanalysis. Psychological bulletin, 141(2), 364. Lareau, A. (2003). Unequal chances: class, race and family life. Berkeley, CA: University of California Press.

Larson, R. W. (1990). The solitary side of life: An examination of the time people spend alone from childhood to old age. Developmental review, 10(2), 155-183.

Larson, R. W., \& Verba, S. (1999). How children and adolescents spend time across the world: work, play, and developmental opportunities. Psychological bulletin, 125(6), 701-736.

Lewis, J., 2009. Work-family Balance, Gender and Policy. Cheltenham: Edward Elgar.

Mullan, K. (2009). Young people's time use and maternal employment in the UK1. The British journal of sociology, 60(4), 741-762.

Nguyen, T. V. T., Ryan, R. M., \& Deci, E. L. (2018). Solitude as an approach to affective selfregulation. Personality and Social Psychology Bulletin, 44(1), 92-106.

Nolan, B., Salverda, W., Checchi, D., Marx, I., McKnight, A., Tóth, I. G., \& van de Werfhorst, H. G. (Eds.). (2014). Changing inequalities and societal impacts in rich countries: thirty countries' experiences. Oxford: Oxford University Press.

OECD, 2016; OECD Family Database. Paris: OECD.

OECD (2017) Social Expenditure Data. Paris: OECD.

O'Keeffe, G. S., \& Clarke-Pearson, K. (2011). Clinical report-the impact of social media on children, adolescents, and families. Pediatrics, (4), 127.

Pfau-Effinger, B. (2005). Culture and welfare state policies: Reflections on a complex interrelation. Journal of social policy, 34(1), 3-20. 
Presser, H. B. (1994). Employment schedules among dual-earner spouses and the division of household labor by gender. American Sociological Review, 59(3), 348-364.

Putnam, R. D. (2001). Bowling alone: The collapse and revival of American community. New York City: Simon and Schuster.

Rees, G. (2017). Children's activities and time use: Variations between and within 16 countries. Children and Youth Services Review, 80, 78-87.

Robinson, J. \& Godbey, G. (1997). Time for life: The surprising ways Americans use their time. The University Park, PA: Penn State University Press.

Sayer, L.C., Gauthier, A.H. \& Furstenberg, F.F., 2004. Educational differences in parents' time with children: Cross-national variations. Journal of marriage and family, 66(5), 1152-1169.

Sayer, L.C.\& Gornick, J.C., (2011). Cross-national variation in the influence of employment hours on child care time. European Sociological Review, 28(4), pp.421-442.

Schmidt, M. E., \& Anderson, D. R. (2007). 'The impact of television on cognitive development and educational achievement.' In N. Pecora, J.P. Murray \& E.A. Wartella (Eds.). (2007). Children and television: Fifty years of research. Mahwah, N.J : Lawrence Erlbaum (pp. 65-84).

Stewart J (2013). Tobit or not tobit? Journal of economic and social measurement 38(3): 263-290.

Thévenon, O. (2011). Family policies in OECD countries: A comparative analysis. Population and development review, 37(1), 57-87.

Triandis, H. C. (2018). Individualism and collectivism. New York: Routledge.

Wang, R., Bianchi, S. M., \& Raley, S. B. (2005). Teenagers' Internet use and family rules: A research note. Journal of Marriage and Family, 67(5), 1249-1258.

Wight, V. R., Price, J., Bianchi, S. M., \& Hunt, B. R. (2009). The time use of teenagers. Social Science Research, 38(4), 792-809.

Zuzanek, J., 2005. Adolescent Time Use and Well-being from a Comparative Perspective. Society \& Leisure. 28(2), 379-423. 
Table 1. Country-Level Differences in Four National Contexts

Finland Italy Spain $\quad U K$
Welfare State Regime ${ }^{1,2}$
Social Democratic Mediterranean Mediterranean Liberal

Maternal Work Tradition ${ }^{3,4}$

Full-Time

Breadwinner

Breadwinner

Part-Time

Work-Family Support 5, 6

High

Low

Low

Low

Individualism or Familism 7,8

Individualism

Familism

Familism

Individualism

Socioeconomic Inequalities $9 \quad$ Low ${ }^{9}$ High $\quad$ High $\quad$ High

Source: Conceptual table by the authors.

${ }^{1}$ See Esping-Andersen (1999) for a classical typology discussing the role of markets, states and families in the provision of welfare across these three regime types.

${ }^{2}$ Public expenditure as percentage of GDP: Finland (30\%), Italy (28\%), Spain (24\%), UK (21\%) (OECD, 2017; Social Expenditure data: https://stats.oecd.org/Index.aspx?DataSetCode=SOCX_AGG).

${ }^{3}$ Maternal employment rates: Finland $=77 \%$; UK $=73 \%$; Spain $=59 \%$; Italy $=56 \%$ (Eurostat, 2017).

${ }^{4}$ Maternal part-time employment (percentage of working-age mothers with children aged 0-14 who work usually less than 30 hours per week in the main job); UK (35\%), Italy (23\%), Spain (19\%), and Finland (8\%). (OECD, 2016; OECD Family Database; www.oecd.org/els/family/database.htm).

${ }^{5}$ Percentage of workers that declare having "the possibility to accumulate hours for days off (full or half days) and to vary the start and end of daily work": Finland $=85 \%$; UK $=50 \%$; Italy $=40 \%$ : Spain $=35 \%$; (OECD Family Database http://www.oecd.org/els/family/database.htm).

${ }^{6}$ See Tevenon (2011) for a differentiation between supportive family-work policies (Finland) and less supportive familywork policies (Italy, Spain, UK), based on the OECD Family Database.

${ }^{7}$ Self-expression values: UK (1.6); Finland (1.3); Italy (0.5); Spain (0.4). Self-expression values indicate the degree to which individuals in a society give higher or lower priority to autonomy and individual-oriented values (including scales with positive and negative values). The first group of items included in this scale relate to the theme of sexual freedom. The second group of items addresses the equal opportunity component of self-expression values in the area of gender equality. The third group of items indicates an emphasis on personal autonomy in educating citizens or children in society (World Values Survey, 2011-2014; Inglehart et al., 2014). While the four countries of our study report positive average values in self-expressionism, numbers are higher in UK and Finland, compared to Italy and Spain.

${ }^{8}$ See Pfau-Effinger (2005) and Saraceno and Kalmijn (2007) for a discussion of categories and typologies considering family support and domestic ideologies and family solidarity in Southern Europe and Europea.

${ }^{9}$ GINI Coefficient: Finland $=0.25$, Italy $=0.33$; $\mathrm{UK}=0.33$; $\mathrm{Spain}=0.34$; The Gini coefficient is the ratio of income inequality between the richest groups of one country and the poorest, with larger numbers indicating higher levels of income inequality, and lower levels leaning towards greater income equality (Eurostat, 2017) 
Table 2. Descriptive Statistics. Means and Standard Deviations in Four Countries

\begin{tabular}{|c|c|c|c|c|c|c|c|c|}
\hline & \multicolumn{2}{|c|}{ Italy } & \multicolumn{2}{|c|}{ Spain } & \multicolumn{2}{|c|}{ United Kingdom } & \multicolumn{2}{|c|}{ Finland } \\
\hline & mean & sd & mean & $\mathrm{sd}$ & mean & $\mathrm{sd}$ & mean & sd \\
\hline Daily Minutes with Others and No Parents & 259.25 & 186.03 & 220.09 & 190.07 & 305.63 & 237.71 & 351.78 & 242.53 \\
\hline Daily Minutes with Parents & 270.66 & 194.21 & 281.61 & 205.85 & 238.11 & 216.03 & 121.27 & 157.50 \\
\hline Daily Minutes in Activities Alone & 171.32 & 145.48 & 183.96 & 161.19 & 163.53 & 173.19 & 233.80 & 186.01 \\
\hline Daily Minutes at School & 185.74 & 163.19 & 185.96 & 187.77 & 155.61 & 175.63 & 158.00 & 167.17 \\
\hline Daily Minutes in Screen-Based Activities & 144.68 & 104.26 & 163.80 & 128.16 & 197.56 & 156.48 & 203.77 & 146.45 \\
\hline Daily Minutes in Educational Activities & 117.28 & 91.58 & 110.71 & 104.63 & 67.42 & 97.65 & 78.56 & 97.42 \\
\hline Daily Minutes in Socializing Activities & 105.12 & 109.57 & 86.56 & 115.95 & 97.12 & 120.49 & 108.55 & 139.63 \\
\hline Daily Minutes Eating Meals & 107.69 & 45.20 & 105.38 & 45.87 & 71.74 & 44.59 & 71.83 & 40.73 \\
\hline Daily Minutes of Sports and Active Leisure & 40.87 & 68.02 & 50.34 & 82.84 & 33.21 & 67.52 & 46.22 & 80.26 \\
\hline Daily Minutes in Domestic Activities & 34.06 & 64.31 & 41.74 & 61.40 & 51.91 & 76.86 & 42.74 & 59.77 \\
\hline Single Mother Family & $13 \%$ & & $16 \%$ & & $31 \%$ & & $21 \%$ & \\
\hline Mother's College Education & $13 \%$ & & $28 \%$ & & $43 \%$ & & $54 \%$ & \\
\hline Mother Not Employed & $43 \%$ & & $38 \%$ & & $31 \%$ & & $18 \%$ & \\
\hline Mother Working 1-30 Hours per Week & $21 \%$ & & $18 \%$ & & $39 \%$ & & $13 \%$ & \\
\hline Mother Working 31-37 Hours per Week & $13 \%$ & & $11 \%$ & & $16 \%$ & & $13 \%$ & \\
\hline Mother Working $>37$ Hours per Week & $22 \%$ & & $33 \%$ & & $13 \%$ & & $56 \%$ & \\
\hline Mother Evening Work & $60 \%$ & & $55 \%$ & & $53 \%$ & & $8 \%$ & \\
\hline Age & 13.60 & 2.26 & 1.47 & 0.50 & 13.37 & 2.29 & 13.51 & 2.36 \\
\hline Girl & $49 \%$ & & $47 \%$ & & $50 \%$ & & $47 \%$ & \\
\hline Weekend Day & $29 \%$ & & $28 \%$ & & $29 \%$ & & $29 \%$ & \\
\hline $1^{\text {st }}$ Quarter Day (January - March) & $24 \%$ & & $26 \%$ & & $27 \%$ & & $28 \%$ & \\
\hline $2^{\text {nd }}$ Quarter Day (April - June) & $25 \%$ & & $24 \%$ & & $26 \%$ & & $21 \%$ & \\
\hline $3^{\text {rd }}$ Quarter Day (July-September) & $26 \%$ & & $22 \%$ & & $26 \%$ & & $24 \%$ & \\
\hline $4^{\text {rd }}$ Quarter Day (October-March) & $25 \%$ & & $28 \%$ & & $21 \%$ & & $27 \%$ & \\
\hline Number of Adults at Home $>17$ years old & 2.27 & 0.76 & 2.33 & 0.82 & 2.12 & 0.73 & 2.04 & 0.58 \\
\hline Number of Children at Home $<18$ years old & 1.77 & 0.79 & 1.80 & 0.77 & 2.14 & 0.99 & 2.12 & 0.77 \\
\hline$N$ & \multicolumn{2}{|c|}{3063} & \multicolumn{2}{|c|}{1324} & \multicolumn{2}{|c|}{1363} & \multicolumn{2}{|c|}{804} \\
\hline
\end{tabular}

Note: Analyses are weighted by day of the week; that is, time-use averages can be read as the average minutes on a random day of a random week of the year. 


\section{Figure 1. Predicted Values. Children's Time Use in Four Countries}

\section{Child Daily Minutes with Parents, Others, Alone or School}
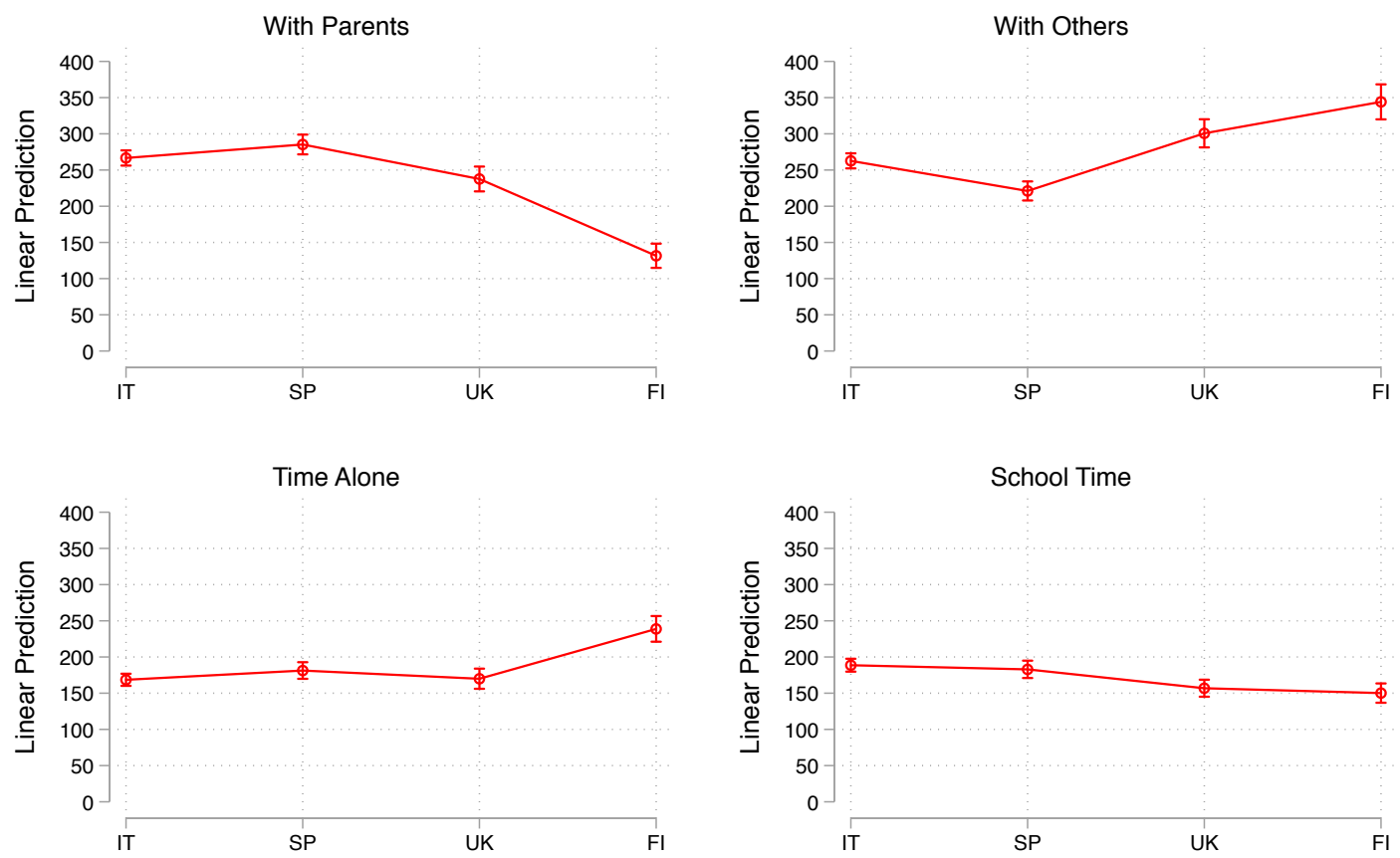

Child Daily Minutues in Specific Activities
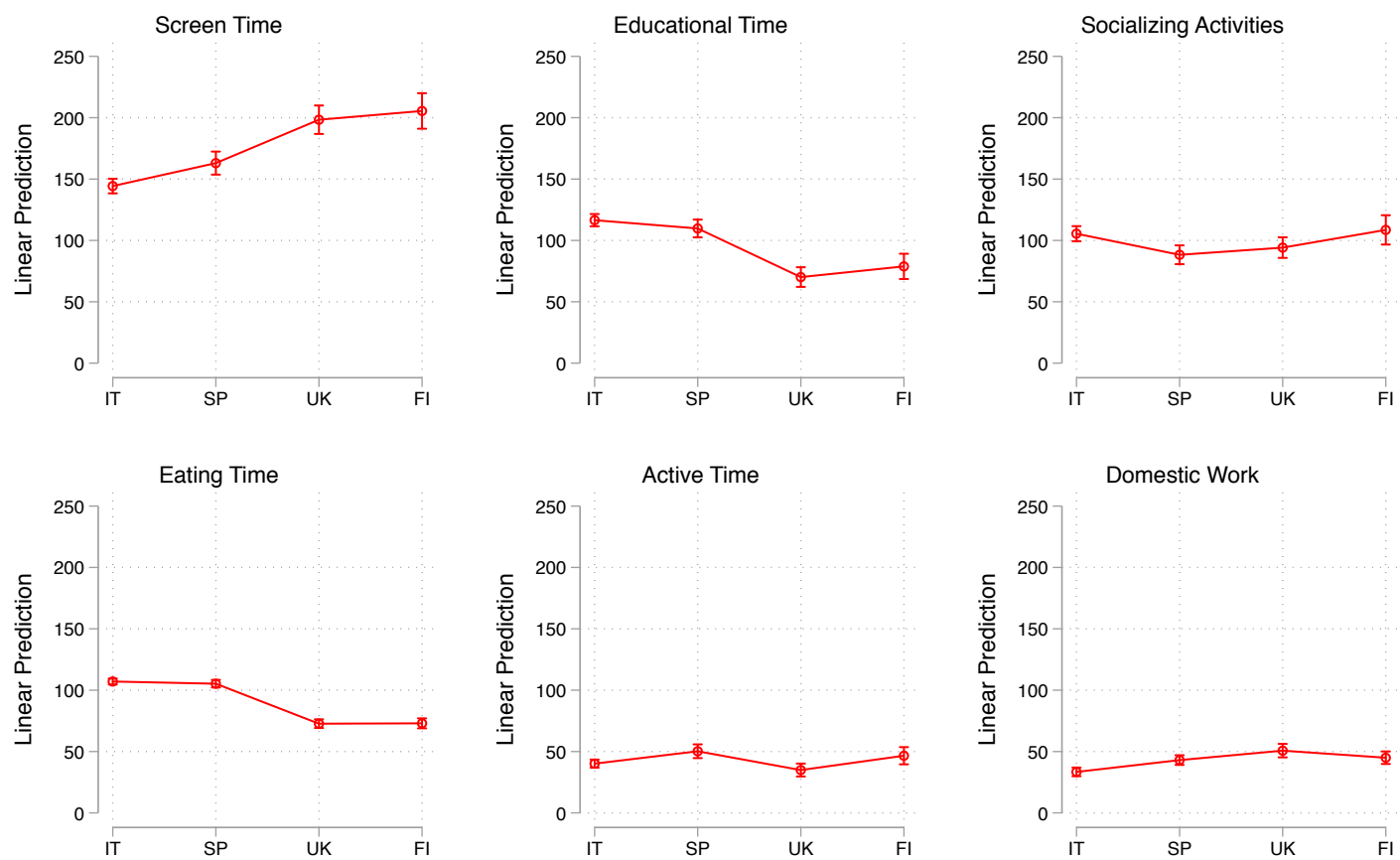

Note: Results are based on predicted values from Linear Regression Models for each country dummy. All models include the following controls: maternal employment, maternal education, family structure, age, gender, number of adults at home, number of children at home, day of the week, quarter of the year. 
Figure 2. Predicted Values. Child Time Use in Four Countries. Country-Level Interactions with Maternal Employment (with Confidence Intervals at 95\%)

Child Daily Minutes with Parents, Others, Alone or School by Maternal Work
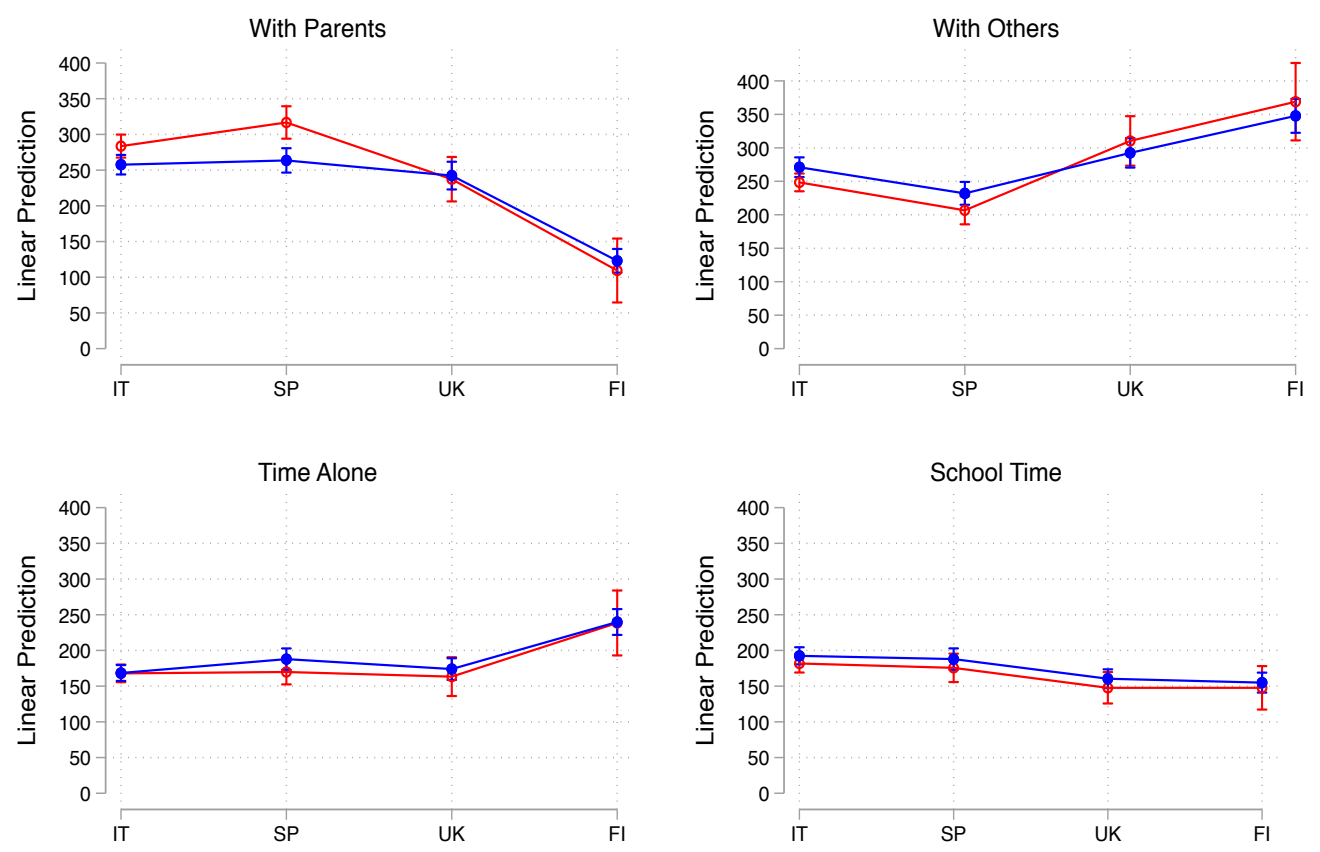

Child Daily Minutes in Specific Activities by Maternal Work
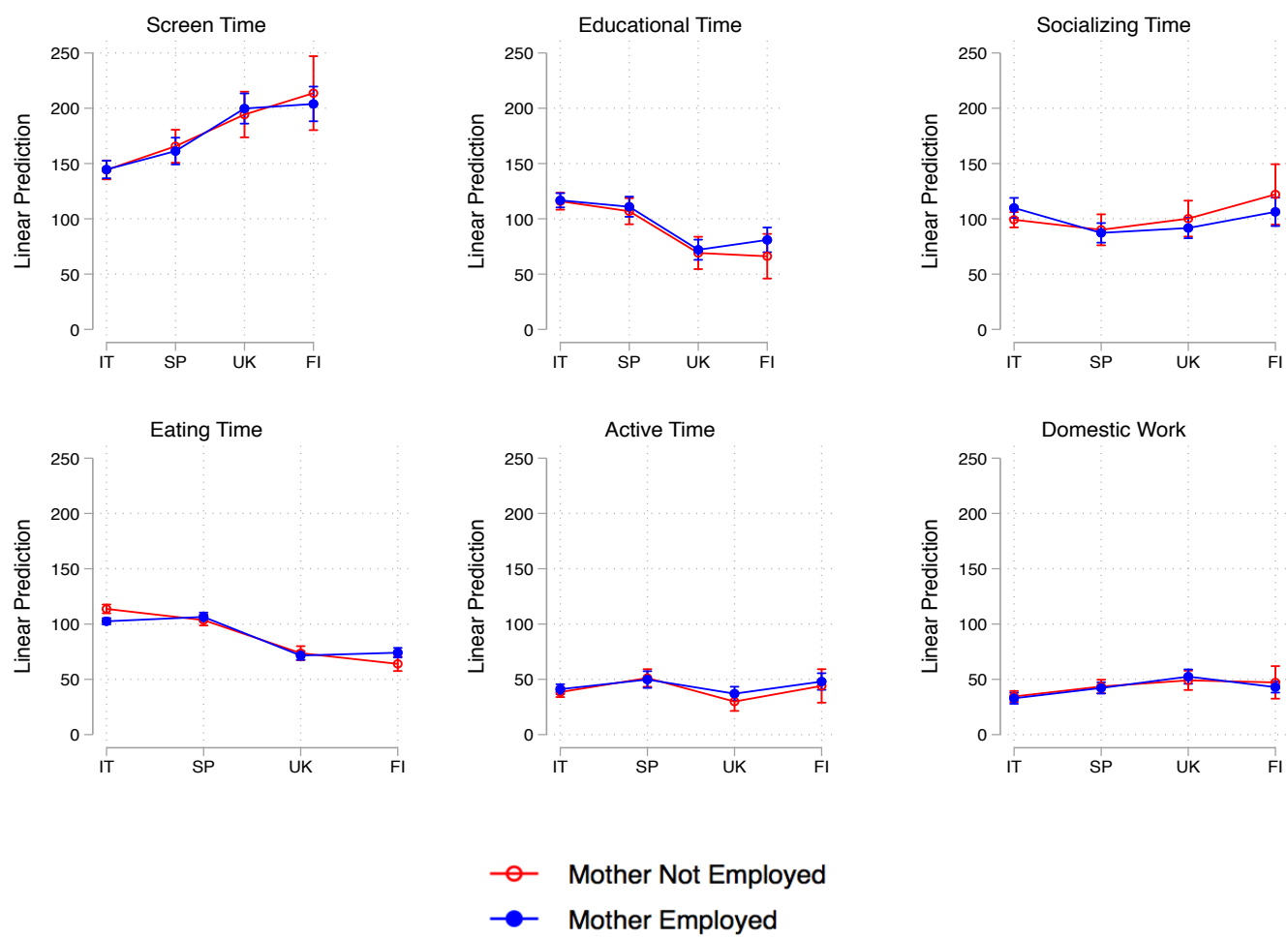

Note: Results are based on predicted values from Linear Regression Models with two-way interactions between country and maternal employment. All models include the following controls: maternal education, family structure, age, gender, number of adults at home, number of children at home, day of week, yearly quarter (CI at the $95 \%$ level are included). 
Figure 3. Predicted Values. Child Time Use in Four Countries. Country-Level Interactions with Maternal Education (with Confidence Intervals at 95\%)

\section{Child Daily Minutes with Parents, Others, Alone or School by Maternal Education}
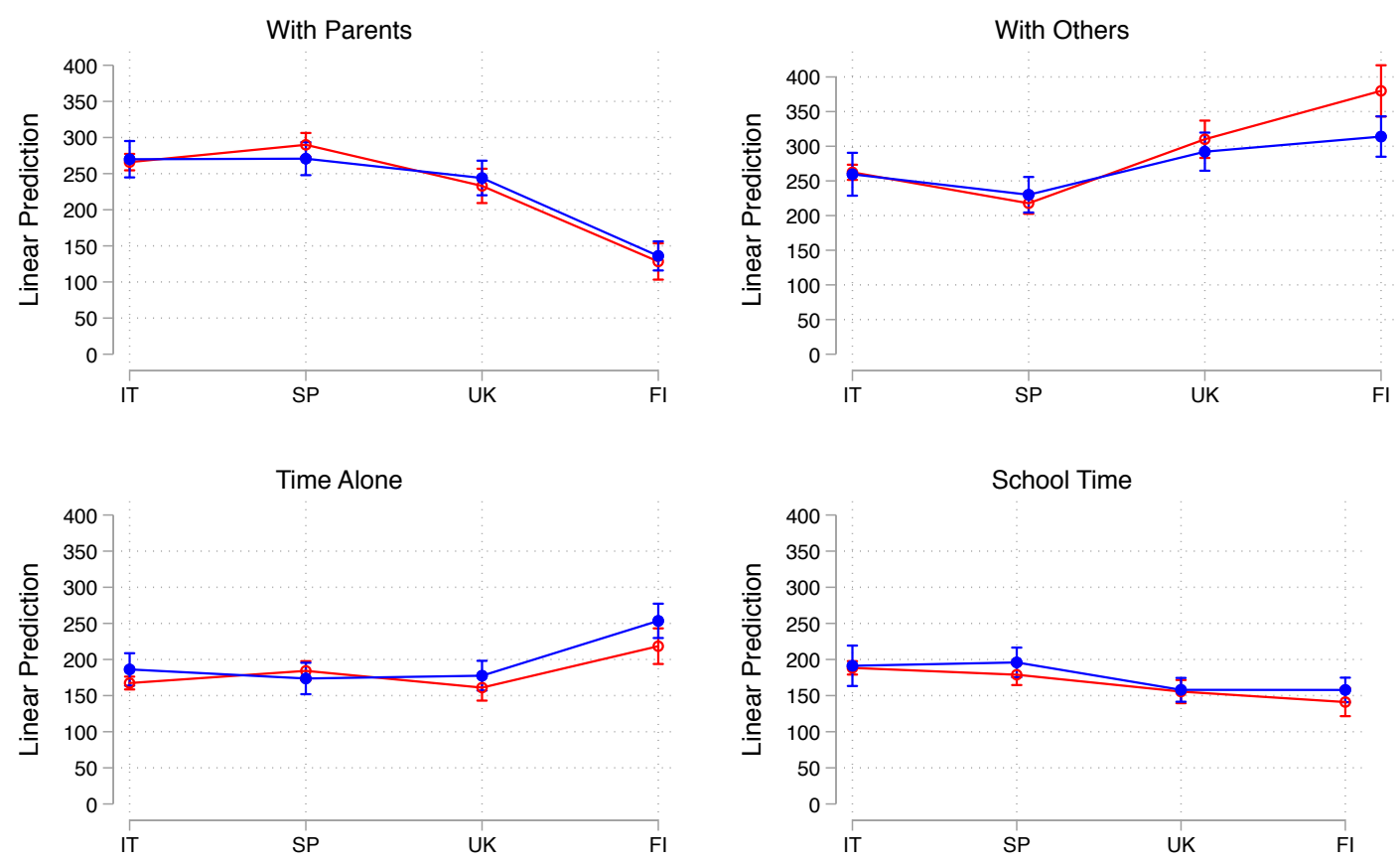

\section{Child Daily Minutes in Specific Activities by Maternal Education}
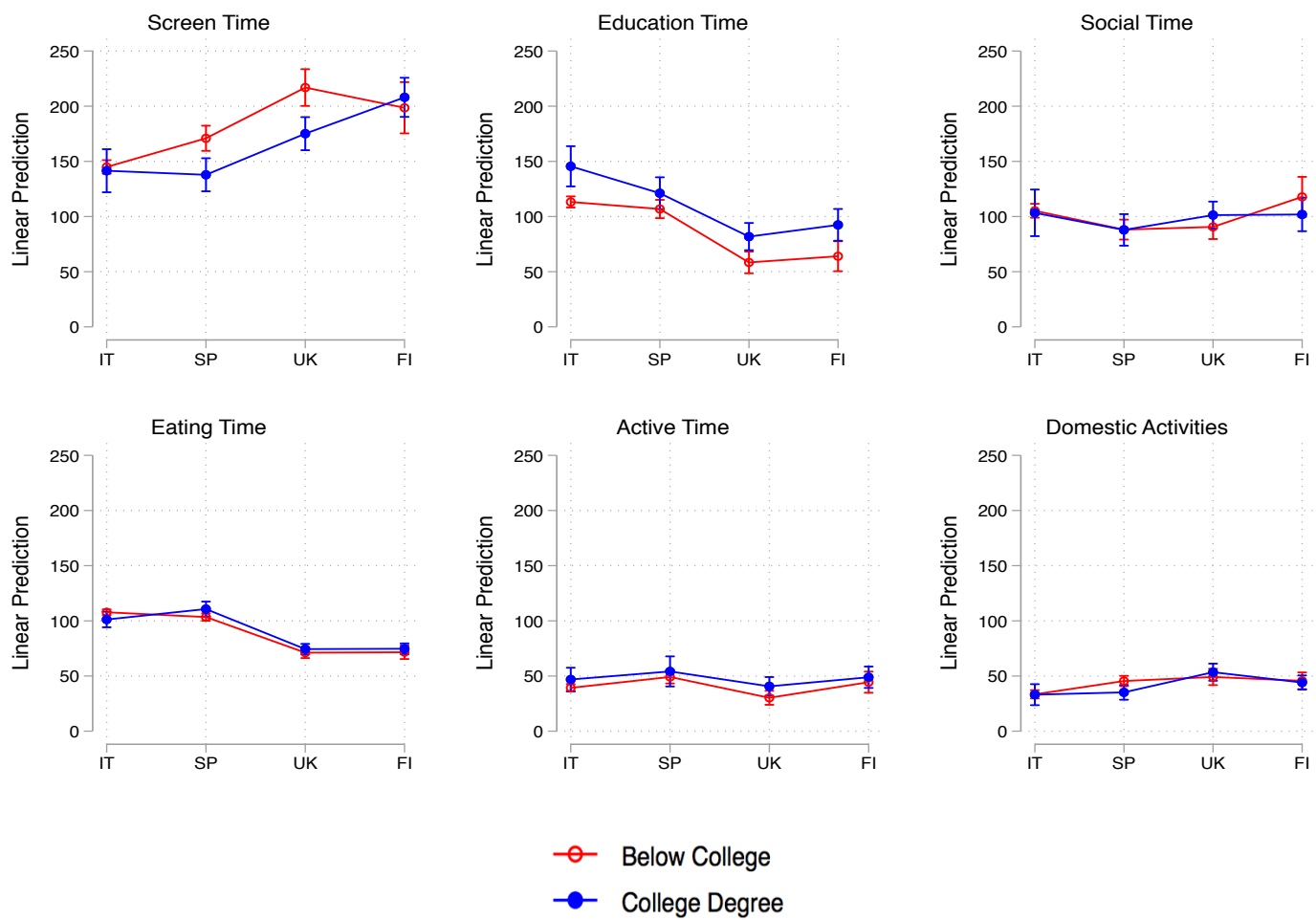

Note: Results are based on predicted values from Linear Regression Models with two-way interactions between country and maternal education. All models include the following controls: maternal employment, family structure, age, gender, number of adults at home, number of children at home, day of week, yearly quarter (CI at the $95 \%$ level are included). 
Figure A1. Average Distribution of Children's Daily Minutes in Selected Activities
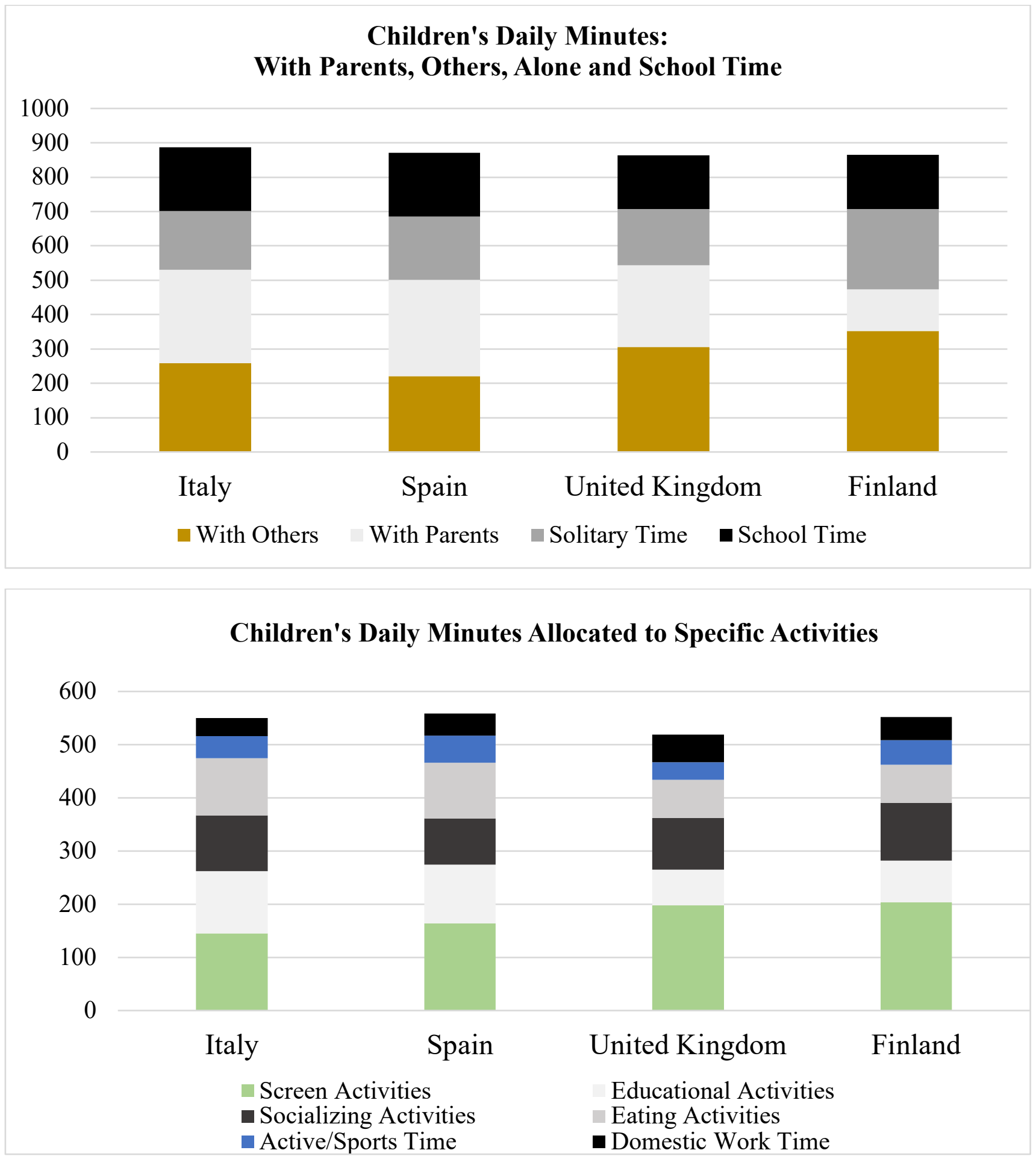

Note: Number of daily minutes on an average day allocated by children -shared with others or not- (upper part) and time in specific activities (bottom part). The specific activities can occur with parents, alone and 'others.' In all figures, the time allocated to sleeping, personal care, resting, commuting, paid work, and "doing nothing" is excluded. 
Table A1. Details on Child Time-Use Activity Coding

\begin{tabular}{|c|c|c|}
\hline General Activities & Activities Included & Location \\
\hline Time with Parents & Any time in presence of at least one parent & Outside School \\
\hline Time with Others & Any time without parents and with others & Outside School \\
\hline Time Alone & Any time without presence of others & Outside School \\
\hline School Time & Any time at school & At School \\
\hline Specific Activities & Activities Included & Location \\
\hline Screen Time & $\begin{array}{l}\text { Computing programming, internet use, computer games, } \\
\text { watching } \mathrm{TV} \text {, video watching }\end{array}$ & Outside School \\
\hline Educational Time & $\begin{array}{l}\text { Reading, study, going to theatre, opera, concerts or cinema, library } \\
\text { time, doing music, dance, theatre, artistic activities }\end{array}$ & Outside School \\
\hline Socializing Activities & $\begin{array}{l}\text { Socializing with family, celebrations, sports events, cultural } \\
\text { visits, religious activities, volunteering }\end{array}$ & Outside School \\
\hline Eating Time & Eating, drinking & Outside School \\
\hline Active Time & Physical activity and sports practice & Outside School \\
\hline Domestic Activities & $\begin{array}{l}\text { Food preparation, washing and cleaning house, ironing, } \\
\text { shopping, gardening, repairs of dwelling, shopping, caring for } \\
\text { children and adults, }\end{array}$ & Outside School \\
\hline
\end{tabular}


Table A2. OLS. Children's Time with Parents, with Others, Alone or at School. Full Models.

\begin{tabular}{|c|c|c|c|c|}
\hline & With Parents & With Others & Time Alone & School Time \\
\hline Spain & $\begin{array}{l}18.71^{*} \\
(8.77)\end{array}$ & $\begin{array}{c}-39.35^{* * *} \\
(8.60)\end{array}$ & $\begin{array}{l}10.35 \\
(7.17)\end{array}$ & $\begin{array}{l}-6.81 \\
(7.64)\end{array}$ \\
\hline United Kingdom & $\begin{array}{l}-29.25^{* *} \\
(10.80)\end{array}$ & $\begin{array}{c}44.71^{* * *} \\
(12.01)\end{array}$ & $\begin{array}{l}-5.67 \\
(8.57)\end{array}$ & $\begin{array}{c}-34.75^{* * *} \\
(8.07)\end{array}$ \\
\hline Finland & $\begin{array}{c}-135.14^{* * *} \\
(10.63)\end{array}$ & $\begin{array}{c}89.10^{* * *} \\
(14.33)\end{array}$ & $\begin{array}{c}62.06^{* * *} \\
(10.27)\end{array}$ & $\begin{array}{c}-41.95^{* * *} \\
(8.84)\end{array}$ \\
\hline Single Mother Household & $\begin{array}{c}-58.75^{* * *} \\
(9.79)\end{array}$ & $\begin{array}{c}41.82^{* * *} \\
(11.66)\end{array}$ & $\begin{array}{c}5.69 \\
(8.61)\end{array}$ & $\begin{array}{c}6.15 \\
(8.17)\end{array}$ \\
\hline Mother's College Educated & $\begin{array}{l}-0.01 \\
(7.93)\end{array}$ & $\begin{array}{c}-18.46^{+} \\
(9.68)\end{array}$ & $\begin{array}{l}20.00^{* *} \\
(7.25)\end{array}$ & $\begin{array}{c}8.50 \\
(6.79)\end{array}$ \\
\hline Mother Works 1-30 Weekly Hours & $\begin{array}{l}-7.44 \\
(9.62)\end{array}$ & $\begin{array}{c}6.73 \\
(9.77)\end{array}$ & $\begin{array}{l}-0.17 \\
(7.73)\end{array}$ & $\begin{array}{c}6.60 \\
(7.54)\end{array}$ \\
\hline Mother Works 31-37 Weekly Hours & $\begin{array}{c}-9.51 \\
(11.58)\end{array}$ & $\begin{array}{c}5.40 \\
(13.10)\end{array}$ & $\begin{array}{c}4.05 \\
(10.22)\end{array}$ & $\begin{array}{c}4.17 \\
(9.02)\end{array}$ \\
\hline Mother Works $>37$ Weekly Hours & $\begin{array}{c}-36.50^{* * *} \\
(9.07)\end{array}$ & $\begin{array}{c}27.95^{* *} \\
(9.67)\end{array}$ & $\begin{array}{l}-0.84 \\
(7.82)\end{array}$ & $\begin{array}{l}12.80^{+} \\
(7.67)\end{array}$ \\
\hline Age & $\begin{array}{c}-19.84^{* * *} \\
(1.42)\end{array}$ & $\begin{array}{c}10.95^{* * *} \\
(1.52)\end{array}$ & $\begin{array}{c}18.64^{* * *} \\
(1.15)\end{array}$ & $\begin{array}{l}-1.20 \\
(1.10)\end{array}$ \\
\hline Girl & $\begin{array}{c}7.32 \\
(6.53)\end{array}$ & $\begin{array}{l}-9.80 \\
(6.95)\end{array}$ & $\begin{array}{c}16.52^{* *} \\
(5.30)\end{array}$ & $\begin{array}{l}-5.35 \\
(4.95)\end{array}$ \\
\hline Weekend & $\begin{array}{c}82.23^{* * *} \\
(5.97)\end{array}$ & $\begin{array}{l}41.68^{* * *} \\
(5.99)\end{array}$ & $\begin{array}{c}3.94 \\
(4.66)\end{array}$ & $\begin{array}{c}-189.60^{* * *} \\
(4.51)\end{array}$ \\
\hline $2^{\text {nd }}$ Quarter (April - June) & $\begin{array}{l}22.78^{*} \\
(9.29)\end{array}$ & $\begin{array}{c}38.10^{* * *} \\
(9.89)\end{array}$ & $\begin{array}{l}14.85^{+} \\
(8.13)\end{array}$ & $\begin{array}{c}-86.33^{* * *} \\
(7.67)\end{array}$ \\
\hline $3^{\text {rd }}$ Quarter (July - September) & $\begin{array}{c}38.90^{* * *} \\
(9.49)\end{array}$ & $\begin{array}{l}44.98^{* * *} \\
(10.46)\end{array}$ & $\begin{array}{c}0.34 \\
(7.96)\end{array}$ & $\begin{array}{c}-97.61^{* * *} \\
(7.40)\end{array}$ \\
\hline $4^{\text {th }}$ Quarter (October - December) & $\begin{array}{l}13.52 \\
(9.02)\end{array}$ & $\begin{array}{l}-12.08 \\
(9.14)\end{array}$ & $\begin{array}{c}5.40 \\
(7.80)\end{array}$ & $\begin{array}{c}-12.31^{+} \\
(6.84)\end{array}$ \\
\hline Number of Adults ( $>17$ years) & $\begin{array}{c}-18.89^{* * *} \\
(5.08)\end{array}$ & $\begin{array}{l}13.81^{*} \\
(5.76)\end{array}$ & $\begin{array}{l}7.79^{+} \\
(4.22)\end{array}$ & $\begin{array}{l}-0.58 \\
(3.91)\end{array}$ \\
\hline Number of Children $(<17$ years $)$ & $\begin{array}{l}-4.71 \\
(4.60)\end{array}$ & $\begin{array}{l}13.34^{* *} \\
(4.88)\end{array}$ & $\begin{array}{c}-11.53^{* * *} \\
(3.46)\end{array}$ & $\begin{array}{c}2.55 \\
(3.46)\end{array}$ \\
\hline Intercept & $\begin{array}{c}563.99^{* * *} \\
(27.22)\end{array}$ & $\begin{array}{c}18.28 \\
(29.02)\end{array}$ & $\begin{array}{c}97.11^{* * *} \\
(21.74)\end{array}$ & $\begin{array}{c}299.45^{* * *} \\
(20.22)\end{array}$ \\
\hline Observations & 6554 & 6554 & 6554 & 6554 \\
\hline Adjusted $R^{2}$ & 0.168 & 0.083 & 0.104 & 0.319 \\
\hline
\end{tabular}

Standard errors in parentheses

${ }^{+} p<.1,{ }^{*} p<.05,{ }^{* *} p<.01,{ }^{* * *} p<.001$ 
Table A3. OLS. Children's Daily Minutes on Various Activities. Full Models.

\begin{tabular}{|c|c|c|c|c|c|c|}
\hline & $\begin{array}{c}\text { Screen } \\
\text { Time }\end{array}$ & $\begin{array}{l}\text { Education } \\
\text { Time }\end{array}$ & $\begin{array}{l}\text { Social } \\
\text { Time }\end{array}$ & $\begin{array}{l}\text { Meals } \\
\text { Time }\end{array}$ & $\begin{array}{l}\text { Active } \\
\text { Time }\end{array}$ & $\begin{array}{l}\text { Domestic } \\
\text { Work }\end{array}$ \\
\hline Spain & $\begin{array}{c}20.86^{* * *} \\
(5.78)\end{array}$ & $\begin{array}{l}-9.76^{*} \\
(4.48)\end{array}$ & $\begin{array}{c}-16.88^{* * *} \\
(5.06)\end{array}$ & $\begin{array}{l}-2.02 \\
(2.00)\end{array}$ & $\begin{array}{l}9.29^{* *} \\
(3.27)\end{array}$ & $\begin{array}{l}9.79^{* * *} \\
(2.72)\end{array}$ \\
\hline United Kingdom & $\begin{array}{c}60.63^{* * *} \\
(7.25)\end{array}$ & $\begin{array}{c}-56.46^{* * *} \\
(5.19)\end{array}$ & $\begin{array}{l}-9.79^{+} \\
(5.60)\end{array}$ & $\begin{array}{c}-35.00^{* * *} \\
(2.36)\end{array}$ & $\begin{array}{l}-7.86^{*} \\
(3.30)\end{array}$ & $\begin{array}{c}18.20^{* * *} \\
(3.43)\end{array}$ \\
\hline Finland & $\begin{array}{c}68.59^{* * *} \\
(8.66)\end{array}$ & $\begin{array}{c}-48.53^{* * *} \\
(6.18)\end{array}$ & $\begin{array}{c}4.54 \\
(7.43)\end{array}$ & $\begin{array}{c}-34.88^{* * *} \\
(2.59)\end{array}$ & $\begin{array}{c}3.61 \\
(4.24)\end{array}$ & $\begin{array}{c}12.36^{* * *} \\
(3.29)\end{array}$ \\
\hline Single Mother Household & $\begin{array}{l}10.05 \\
(6.89)\end{array}$ & $\begin{array}{l}-9.20^{+} \\
(4.94)\end{array}$ & $\begin{array}{c}1.76 \\
(5.31)\end{array}$ & $\begin{array}{l}-6.21^{* *} \\
(2.36)\end{array}$ & $\begin{array}{l}-8.88^{* *} \\
(3.09)\end{array}$ & $\begin{array}{l}-3.17 \\
(3.01)\end{array}$ \\
\hline Mother College Educated & $\begin{array}{c}-17.70^{* *} \\
(5.93)\end{array}$ & $\begin{array}{c}25.31^{* * *} \\
(4.72)\end{array}$ & $\begin{array}{l}-3.04 \\
(5.02)\end{array}$ & $\begin{array}{c}1.91 \\
(1.98)\end{array}$ & $\begin{array}{c}6.57^{*} \\
(3.11)\end{array}$ & $\begin{array}{l}-1.64 \\
(2.58)\end{array}$ \\
\hline Mother Works 1-30 Weekly Hours & $\begin{array}{l}-4.97 \\
(5.78)\end{array}$ & $\begin{array}{c}2.92 \\
(4.82)\end{array}$ & $\begin{array}{c}5.07 \\
(5.25)\end{array}$ & $\begin{array}{l}-4.87^{*} \\
(2.17)\end{array}$ & $\begin{array}{c}1.95 \\
(3.09)\end{array}$ & $\begin{array}{c}2.20 \\
(3.21)\end{array}$ \\
\hline Mother Works 31-37 Weekly Hours & $\begin{array}{l}14.27^{+} \\
(7.91)\end{array}$ & $\begin{array}{c}0.99 \\
(5.26)\end{array}$ & $\begin{array}{l}-3.54 \\
(6.31)\end{array}$ & $\begin{array}{l}-4.70^{+} \\
(2.44)\end{array}$ & $\begin{array}{l}-0.32 \\
(3.55)\end{array}$ & $\begin{array}{c}2.05 \\
(3.51)\end{array}$ \\
\hline Mother Works $>37$ Weekly Hours & $\begin{array}{l}-0.19 \\
(5.94)\end{array}$ & $\begin{array}{l}-1.99 \\
(4.61)\end{array}$ & $\begin{array}{c}3.81 \\
(5.35)\end{array}$ & $\begin{array}{l}-3.99^{+} \\
(2.06)\end{array}$ & $\begin{array}{c}2.67 \\
(3.20)\end{array}$ & $\begin{array}{l}-2.84 \\
(3.15)\end{array}$ \\
\hline Age & $\begin{array}{c}2.37^{*} \\
(0.92)\end{array}$ & $\begin{array}{l}4.08^{* * *} \\
(0.73)\end{array}$ & $\begin{array}{c}-4.42^{* * *} \\
(0.84)\end{array}$ & $\begin{array}{c}-1.04^{* * *} \\
(0.31)\end{array}$ & $\begin{array}{c}0.50 \\
(0.50)\end{array}$ & $\begin{array}{c}2.18^{* * *} \\
(0.51)\end{array}$ \\
\hline Girl & $\begin{array}{c}-35.91^{* * *} \\
(4.20)\end{array}$ & $\begin{array}{c}20.79^{* * *} \\
(3.24)\end{array}$ & $\begin{array}{c}1.37 \\
(3.76)\end{array}$ & $\begin{array}{l}-3.47^{*} \\
(1.43)\end{array}$ & $\begin{array}{c}-11.84^{* * *} \\
(2.24)\end{array}$ & $\begin{array}{c}25.70^{* * * *} \\
(2.18)\end{array}$ \\
\hline Weekend & $\begin{array}{c}34.32^{* * *} \\
(3.71)\end{array}$ & $\begin{array}{c}-18.29^{* * *} \\
(2.89)\end{array}$ & $\begin{array}{c}54.08^{* * *} \\
(3.71)\end{array}$ & $\begin{array}{c}16.17^{* * *} \\
(1.43)\end{array}$ & $\begin{array}{c}18.56^{* * *} \\
(2.30)\end{array}$ & $\begin{array}{c}14.28^{* * *} \\
(2.04)\end{array}$ \\
\hline $2^{\text {nd }}$ Quarter (April - June) & $\begin{array}{c}2.42 \\
(6.15)\end{array}$ & $\begin{array}{l}-1.96 \\
(4.98)\end{array}$ & $\begin{array}{c}30.38^{* * *} \\
(5.16)\end{array}$ & $\begin{array}{l}9.10^{* * *} \\
(2.16)\end{array}$ & $\begin{array}{c}10.70^{* * *} \\
(3.13)\end{array}$ & $\begin{array}{c}15.62^{* * *} \\
(2.78)\end{array}$ \\
\hline $3^{\text {rd }}$ Quarter (July - September) & $\begin{array}{l}16.38^{*} \\
(6.40)\end{array}$ & $\begin{array}{c}-16.53^{* * *} \\
(4.60)\end{array}$ & $\begin{array}{c}31.46^{* * *} \\
(5.47)\end{array}$ & $\begin{array}{l}4.31^{*} \\
(2.14)\end{array}$ & $\begin{array}{c}15.26^{* * *} \\
(3.48)\end{array}$ & $\begin{array}{c}22.17^{* * *} \\
(2.90)\end{array}$ \\
\hline $4^{\text {th }}$ Quarter (October - December) & $\begin{array}{c}5.40 \\
(6.00)\end{array}$ & $\begin{array}{c}8.50^{+} \\
(4.51)\end{array}$ & $\begin{array}{l}-2.87 \\
(5.07)\end{array}$ & $\begin{array}{c}0.57 \\
(2.11)\end{array}$ & $\begin{array}{l}-5.17^{+} \\
(2.71)\end{array}$ & $\begin{array}{l}5.82^{*} \\
(2.81)\end{array}$ \\
\hline Number of Adults ( $>17$ years) & $\begin{array}{l}7.26^{*} \\
(3.40)\end{array}$ & $\begin{array}{l}-1.80 \\
(2.21)\end{array}$ & $\begin{array}{l}-0.14 \\
(2.60)\end{array}$ & $\begin{array}{l}-0.29 \\
(1.24)\end{array}$ & $\begin{array}{l}-0.95 \\
(1.66)\end{array}$ & $\begin{array}{l}-0.37 \\
(1.54)\end{array}$ \\
\hline Number of Children ( $<17$ years) & $\begin{array}{l}-3.58 \\
(2.80)\end{array}$ & $\begin{array}{c}0.88 \\
(2.14)\end{array}$ & $\begin{array}{c}1.17 \\
(2.31)\end{array}$ & $\begin{array}{l}-0.16 \\
(0.92)\end{array}$ & $\begin{array}{l}-1.69 \\
(1.31)\end{array}$ & $\begin{array}{c}0.49 \\
(1.38)\end{array}$ \\
\hline Intercept & $\begin{array}{c}103.77^{* * *} \\
(17.40)\end{array}$ & $\begin{array}{c}60.05^{* * *} \\
(12.00)\end{array}$ & $\begin{array}{c}130.87^{* * *} \\
(14.60)\end{array}$ & $\begin{array}{c}119.53^{* * *} \\
(5.61)\end{array}$ & $\begin{array}{c}33.86^{* * *} \\
(9.02)\end{array}$ & $\begin{array}{c}23.01^{* *} \\
(8.53)\end{array}$ \\
\hline Observations & 6554 & 6554 & 6554 & 6554 & 6554 & 6554 \\
\hline Adjusted $R^{2}$ & 0.080 & 0.089 & 0.073 & 0.156 & 0.041 & 0.079 \\
\hline
\end{tabular}

Standard errors in parentheses

${ }^{+} p<.1,{ }^{*} p<.05,{ }^{* *} p<.01,{ }^{* * *} p<.001$ 